AL-TA'LIM JOURNAL, 23 (3), 2016, (201-213)

(Print ISSN 1410-7546 Online ISSN 2355-7893)

Available online at http://journal.tarbiyahiainib.ac.id/index.php/attalim

\title{
A Learning Process Evaluation Model for the Integrated Islamic Elementary School
}

\author{
Received: 09 ${ }^{\text {th }}$ April2016; Revised: $12^{\text {th }}$ April 2016; Accepted: $20^{\text {th }}$ July 2016
}

Permalink/DOI: http://dx.doi.org/10.15548/it.v23i3.245

\section{Retno Wahyuningsih*) \\ Institut Agama Islam Negeri Surakarta, Central of Java, Indonesia \\ Email: retnowahyuningsih2008@gmail.com}

\section{Khuriyah \\ Institut Agama Islam Negeri Surakarta, Central of Java, Indonesia \\ Email: khuriyah.white@gmail.com}

*) Corresponding Author

\begin{abstract}
The study was to: 1) generate the appropriate evaluation instrument so that the instrument might be implemented in evaluating the Integrated Islamic Elementary School (SDIT, Sekolah Dasar Islam Terpadu) learning process; 2) identify the effectiveness of the developed evaluation instrument; and 3) identify the description and the criteria in the results of evaluation conducted in the Integrated Islamic Elementary School. The study was categorized as an evaluation research that applied the CIPP evaluation model (the aspects that had been selected were the input and the process), namely the one that referred to the steps in the research and development efforts in order to develop the instrument for evaluating the learning process in the Integrated Islamic Elementary School. The conclusions of the study, then, are as follows: 1) the study has generated the Integrated Islamic Elementary School Learning Process Evaluation Model (P3) and the P3 Model that has been developed refers to the theory of Borg \& Gall that consists of 9 stages; 2) the P3 Model has a "Very Good" effectiveness based on the reviewer assessment and has met the standards of a tool that might be applied for evaluating the learning process in the Integrated Islamic Elementary School; and 3) the criteria in the P3 Model might provide a factual and overall description regarding the learning process in the Integrated Islamic Elementary School.
\end{abstract}

Keywords: Evaluation model, learning model, integrated Islamic elementary school

How to Cite: Wahyuningsih, R., \& Khuriyah, K. (2016). A Learning process evaluation model for the integrated Islamic elementary school. Al-Ta Lim Journal, 23(3). doi: http://dx.doi.org/10.15548/jt.v23i3.245

\section{INTRODUCTION}

In the Law Number 20 Year 2003 Regarding the National Education System Verse 1, it has been mentioned that education is a conscious and planned effort toward manifesting the learning process and the learning situation in order that the learning participants actively develop their selfpotentials so that they will be able to attain their spiritual-religious strength, self-control, personality, intelligence, nobility and skills that will be necessary for themselves, the community, the nation and the state.

Reviewing the meaning of education in the above statements, the researchers found several keywords namely active learning, spiritual religiousness, personality, nobility and skills. If the law might be implemented into the policies of teaching and educating activities in Indonesia, then the Indonesian 
people will be able to compete in the global stage, especially when policies might be collaborated into the concept of Islamic education. Unfortunately, the recent educational system is still far from the Islamic values and the law itself. Indeed, there are several educational institutions that have been encouraged to develop a competitive educational system; however, in general the national and fundamental educational system and policy that support the modern Islamic education have not been designed.

Over time, there are more Islamic schools that appear in the Islamic education around the Southeast Asian regions especially in Indonesia; these schools are very popular and one type of these schools is the integrated Islamic school. Having been established since 1993 and having developed rapidly after the Reformation, there are around 1000 integrated Islamic schools throughout Indonesia. This condition is very good for the Islamic education in Indonesia where the Islamic movement in the era of New Order was considered as "the right extreme" that endangered the unity of the Pancasilaprincipled Republic of Indonesia.

In order to preserve the quality of the integrated Islamic schools, a number of Islamic education practitioners and observers have established an association of Integrated Islamic School Network (JSIT, Jaringan Sekolah Islam Terpadu). According to Syarifudin (2009), the JSIT is an institution that affords to empower the Islamic schools. The main mission of JSIT is to be Islamic, be effective and be qualified. Up to date, the members of JSIT are 200 schools, ranging from the kindergartens to the senior high schools, and 1000 integrated Islamic schools throughout Indonesia.

The integration of Islamic values into the learning process within the curriculum of Islamic education until now still encounters the difficulties in integrating the two different poles of dual scientific paradigms. Based on the above dichotomy, according to Mahzar (2004), the curriculum of general education and that of Islamic education still in their own position; as a result, their learning process is still partial and fragmented among the science, the divine revelation and the natural science; whereas, according to the terminology of Islamic philosophy, God derived the Al-Qur'an in the recorded form (recorded Qur'an), namely the revelation that has been written in a book that the Islamic people read every day, and the created form (created Qur'an), namely the earth and the universe.

According to Muhab (2010), actually the Islamic Integrated Schools (SIT, Sekolah Islam Terpadu) in their learning process have already had the quality standards that serve as the guidelines in evaluating their learning process. However, these standards should be designed under the technical operational manner into an instrument so that the instrument might be implemented for evaluating the learning process of the Islamic integrated schools in order to identify whether the standards that have been applied meet the demands of the integrated Islamic schools' quality or not.

Some studies observe a correlation between teachers' results in their evaluations and those of their students. However, the positive effects of teachers' evaluations cannot be felt unless certain conditions, such as wider definitions of leadership in schools are present, teaching personnel conducts selfevaluations and evaluators themselves receive training to improve the teachers' evaluation process (Bouchamma, 2005).

Based on the explanation, the study then is to: 1) generate an appropriate evaluation instrument that might be implemented for evaluating the Integrated Islamic Elementary School (SDIT, Sekolah Dasar Islam Terpadu); 2) identify the effectiveness of the evaluation instrument that will be developed; and 3) identify the description and the criteria in the results of evaluation that has been conducted in the SDIT. 


\section{METHOD}

The study was categorized as an evaluation research that implemented the CIPP evaluation model (the aspects that had been selected were the input and the process), namely the one that implemented the steps in the research and development research in developing the instrument for evaluation the learning process within the Integrated Islamic
Elementary School (SDIT). Borg \& Gall (1984) stated that research and development consisted of a cycle in which the product would be developed, be field-tested and be revised based on the field-test data. The educational product that the researchers would like to generate in the study would be an appropriate evaluation instrument for evaluating the learning process in the SDIT.

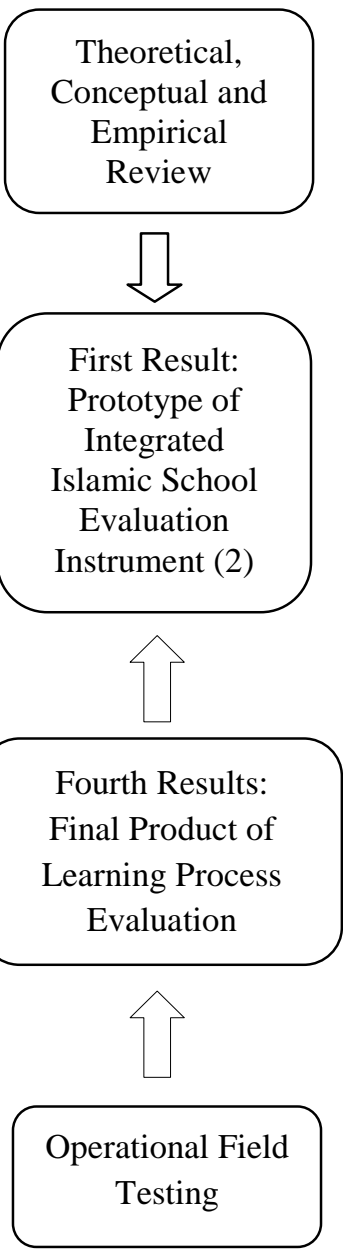

Figure 1. The Steps of P3 Model Development

The study was conducted in the exSurakarta Residency region and the units of analysis for the evaluation model development were the Integrated Islamic Schools that had been located in the region. Recalling the researchers' limitations, not all of the Integrated Islamic Schools would be investigated. The Integrated Islamic Schools that would be investigated were the representatives of the Integrated Islamic Elementary School (SDIT). Then, the study was conducted from June until October 2014.
The population in the study was the Integrated Islamic Elementary Schools in the ex-Surakarta Residency region and there were 26 units of the Integrated Islamic Elementary Schools. However, not all of the population members would be investigated recalling multiple limitations that the researchers had. The samples in the study were three Integrated Islamic Elementary Schools that had been the representatives from each region in the Surakarta and these samples were selected by means of simple random sampling. The units of analysis in the study 
were the caretakers of the integrated Islamic elementary schools. In overall, the research and development study involved 96 respondents who had been the part of the SIT
(Sekolah Islam Terpadu, Integrated Islamic School) units of analysis and these respondents would be detailed in the following table:

Table 1. The Respondents of Developmental Testing

\begin{tabular}{lrrrrr}
\hline \multirow{2}{*}{ Components } & \multirow{2}{*}{ Delphi } & Expert & \multicolumn{2}{c}{ Testing } & \multirow{2}{*}{ Total } \\
& & Judgment & Main & Operational & \\
\hline Principal & 0 & 0 & 1 & 2 & 3 \\
Teachers & 0 & 0 & 10 & 20 & 30 \\
Experts and Practitioners & 56 & 7 & 0 & 0 & 7 \\
\hline Total & $\mathbf{5 6}$ & $\mathbf{7}$ & $\mathbf{1 1}$ & $\mathbf{2 2}$ & $\mathbf{9 6}$ \\
\hline
\end{tabular}

The study was designed to be conducted in two stages. The first stage was the research stage that had been the first step, namely the step in gathering information in the theory of R\&D proposed by Borg \& Gall. In this stage, the researchers conducted a preliminary study in order to identify the demands toward the evaluation model for the operationalization of integrated Islamic schools. Then, the second stage was the development stage that consisted of the second step through the ninth step in the theory of R\&D proposed by Borg \& Gall (1984).

Before designing the data gathering instrument in the form of learning process evaluation questionnaire, the researchers would like to define the instrument guidelines as follows:

Table 2. Evaluation Model of Instrument Prototype

\begin{tabular}{|c|c|c|c|c|c|}
\hline No. & Evaluation & Components & Indicators & Items & Data Gathering \\
\hline \multirow[t]{6}{*}{1} & Input & 1. Curriculum & 1. Curriculum design & 1. $1-13$ & Documentation \\
\hline & & & 2. Curriculum criteria & 2. $14-23$ & \\
\hline & & 2. Documents of & 1. Curriculum analysis & 1. $1-8$ & \\
\hline & & learning & 2. Syllabus design & 2. $9-13$ & \\
\hline & & process & 3. Lesson plan design & 3. $14-27$ & \\
\hline & & standards & 4. Learning instruments & 4. $28-37$ & \\
\hline \multirow[t]{9}{*}{2} & Process & 1.Learning & 1. Preliminary activities & 1. $1-5$ & Questionnaire \\
\hline & & process & 2. Main activities & 2. $6-23$ & \\
\hline & & activities & 3. Closing activities & 3. $24-28$ & \\
\hline & & 2. Classroom & 1. Classroom culture & 1. $29-31$ & \\
\hline & & management & $\begin{array}{l}\text { 2. Classroom culture and logical } \\
\text { consequence }\end{array}$ & 2. $32-34$ & \\
\hline & & & $\begin{array}{l}\text { 3. Communication between teachers } \\
\text { and learning participants }\end{array}$ & 3. $35-39$ & \\
\hline & & & 4. Learning assessment & 4. $40-42$ & \\
\hline & & & 5. Matriculation & 5. $43-46$ & \\
\hline & & & $\begin{array}{l}\text { 6. Learning process control and } \\
\text { supervision }\end{array}$ & 6. $47-57$ & \\
\hline
\end{tabular}

The data analysis technique that the researchers would to implement in the study was the descriptive quantitative technique with the narrative text that would be in accordance with the importance of the study. On the other hand, the data analysis in the stage of model development would be conducted by implementing both the quantitative descriptive and the qualitative descriptive approach. The data that had been attained from the Delphi method, the instrument assessment sheet completed by the 
reviewers, the results of input evaluation and the results of Integrated Islamic Elementary School process quality evaluation would be analyzed under the descriptive quantitative manner and the analysis included: a) calculating the necessary mean, percentage and descriptive statistic; b) creating the table of frequency distribution complete with the percentage and the categorization; and c) defining the criteria of Integrated Islamic Elementary School learning process. For the descriptive data processing, the researchers would operate the Microsoft Excel software. Then, the qualitative data in the form of indepth interview would be described narratively and would be implemented for explaining and supporting the quantitative analysis.

The analysis toward the data that had been resulted from the main testing and the operational testing would be benefitted for identifying the construct validity and reliability of the instrument in the P3 Model. The validity test would be conducted by operating the EFA with the assistance of SPSS 17 program, while the reliability test would be identified through the Cronbach Alpha parameter with the assistance of SPSS 17 program.

Table 3. The Summary of Data Analysis Technique

\begin{tabular}{|ll}
\hline \multicolumn{1}{c}{$\begin{array}{c}\text { Data Analysis } \\
\text { Technique }\end{array}$} & \multicolumn{1}{c}{ Implementation } \\
\hline $\begin{array}{l}\text { Descriptive } \\
\text { statistics by } \\
\text { means of Excel } \\
\text { program }\end{array}$ & $\begin{array}{l}\text { Calculating the mean, the } \\
\text { percentage and the criteria } \\
\text { definition that has been attained } \\
\text { from the preliminary study, the } \\
\text { Delphi technique, the expert } \\
\text { validation and the reviewers' } \\
\text { instrument assessment sheet }\end{array}$ \\
& $\begin{array}{l}\text { Instrument validity test that had } \\
\text { been attained from the main } \\
\text { testing and the operational } \\
\text { of SPSS 17 }\end{array}$ \\
testing means \\
Reliability instrument test that \\
had been attained from the main \\
testing and the operational \\
testing
\end{tabular}

In order to find the criteria of importance level through the Delphi method, the researchers would use the following table on the criteria of importance level:

Table 4. The Criteria of the Component's Importance Level within the Evaluation Model

\begin{tabular}{cc}
\hline Percentage & Criteria \\
\hline $1 \%-25.99 \%$ & Not Important \\
$26 \%-50.99 \%$ & Less Important \\
$51 \%-75.99 \%$ & Important \\
$76 \%-100 \%$ & Very Important \\
\hline
\end{tabular}

Then, for the criteria of the integrated Islamic school learning process the researchers would the following table.

Table 5. Criteria on the Integrated Islamic Elementary School Learning Process

\begin{tabular}{ccc}
\hline No & Score & Category \\
\hline 1 & $1-1.599$ & Very Poor \\
2 & $1.6-2.199$ & Poor \\
3 & $2.2-2.799$ & Moderate \\
4 & $2.8-3.399$ & Good \\
5 & $3.4-4.0$ & Very Good \\
\hline
\end{tabular}

\section{RESULTS AND DISCUSSIONS}

The development of the learning process evaluation model in the Integrated Islamic Elementary Schools was conducted by adopting and by modifying the development model proposed by Borg \& Gall (1984) through the following steps. First, the researchers developed the preliminary form of product. In this step, the researchers developed the model design by having confirmation from the experts, the practitioners and the managers of the Integrated Islamic Elementary Schools regarding the important indicators that should be displayed in the evaluation model that would be developed by means of Delphi technique. Technically, the Delphi technique was implemented through two rounds. The respondents in first round of Delphi technique implementation were 26 people, while the respondents in the second round of Delphi technique implementation were 30 people. These respondents included the educational experts, the educational practitioners and the manager of Integrated Islamic Schools. The 
results from the first round of Delphi

in the following table. technique implementation would be presented

Table 6. Percentage of the P3 Components in the First Round Delphi

\begin{tabular}{clrrrrc}
\hline Components & \multicolumn{1}{c}{ Dimensions } & Max & \multicolumn{1}{c}{ Score } & $\%$ & Criteria \\
\hline \multirow{2}{*}{ Learning } & 1. Learning process & 104 & 93 & 89.0 & Very Important \\
Process & 2. Learning process in the classroom & 104 & 95 & 91.0 & Very Important \\
& 3. Classroom management & 104 & 99 & 95.0 & Very Important \\
\multirow{2}{*}{ Curriculum } & 3. Integrated Islamic Elementary & School & 104 & 99 & 95.2 & Very Important \\
\hline
\end{tabular}

Quantitatively, all of the components and the dimensions in the management of Integrated Islamic Schools within the first round of Delphi technique implementation met the "Very Important" category so that these components should be displayed in the evaluation model of Integrated Islamic Schools. Then, the results from the second round of Delphi technique implementation would be presented in the following table.

Table 7. Percentage of the P3 Component's Importance Level in the Second Round Delphi

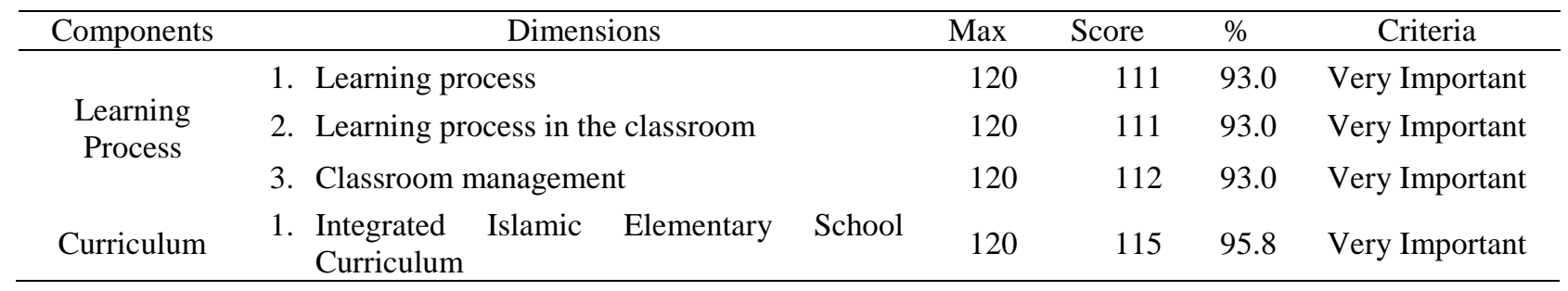

Quantitatively, in the second round of Delphi technique implementation the researchers found that there had been three components of learning process that met the "Very Important" category so that these components should be displayed in the evaluation model.

Second, the researchers would perform the preliminary field testing. In this step, the researchers performed the expert validation regarding the evaluation model that had been assessed previously by the reviewers, namely the experts and the educational practitioners in the Delphi technique. The respondents in the field testing were the experts and the practitioners of education, evaluation, Integrated Islamic Schools and Islam; the total number of the respondents was 7 people.

Table 8. Percentage of the P3 Instrument's General Feasibility Assessment by the Experts

\begin{tabular}{clcccc}
\hline No & \multicolumn{1}{c}{ Indicators } & Max & Score & $\%$ & Criteria \\
\hline 1 & Cover & 35 & 33 & 94.0 & Very Good \\
2 & Content & 35 & 32 & 91.0 & Very Good \\
3 & Scope of evaluation & 35 & 30 & 86.0 & Very Good \\
4 & Scope of component elaboration & 35 & 30 & 86.0 & Very Good \\
5 & Level of readability & 35 & 32 & 91.0 & Very Good \\
6 & Easiness of understanding & 35 & 30 & 86.0 & Very Good \\
7 & Writing mechanics & 35 & 34 & 97.0 & Very Good \\
8 & Language use & 35 & 31 & 89.0 & Very Good \\
9 & Composition layout & 35 & 32 & 91.0 & Very Good \\
10 & The selection of letter, font and space & 35 & 33 & 94.3 & Very Good \\
11 & Page thickness & 35 & 30 & 85.7 & Very Good \\
12 & Practicality & 35 & 29 & 83.0 & Very Good \\
13 & Time effectiveness & 35 & 30 & 86.0 & Very Good \\
14 & Evaluation achievement & 35 & 32 & 91.0 & Very Good \\
\hline
\end{tabular}


Table 9. Percentage of the P3 Instrument's General Feasibility Assessment by the Experts

\begin{tabular}{|c|c|c|c|c|c|}
\hline Components & Dimensions & $\operatorname{Max}$ & Score & $\%$ & Criteria \\
\hline \multirow{3}{*}{ Learning Process } & 1. Learning process & 35 & 31 & 89.0 & Very Good \\
\hline & $\begin{array}{l}\text { 2. Learning process in the } \\
\text { classroom }\end{array}$ & 35 & 32 & 91.0 & Very Good \\
\hline & 3. Classroom management & 35 & 32 & 91.0 & Very Good \\
\hline Curriculum & $\begin{array}{l}\text { 1. Integrated Islamic Elementary } \\
\text { School Curriculum }\end{array}$ & 35 & 31 & 88.0 & Very Good \\
\hline
\end{tabular}

The criteria that the researchers implemented in determining whether the components of Integrated Islamic Schools learning process had been feasible or not for evaluation were as follows: if the percentage of the components had been above $61 \%$ (Good) and been above 81\% (Very Good), then the components would be displayed in the evaluation model. Therefore, furthermore in the second step the researchers would calculate the score and the percentage of feasibility level that would be compared to the criteria that had been defined. The instrument validation had five options (very poor, poor, moderate, good and very good) that might be selected by the seven experts. Quantitatively, all components in the learning process of Islamic Integrated Schools, based on the expert judgment, had met the "Very Good" criteria and, therefore, might be implemented in evaluating the learning process of Integrated Islamic Schools.

Third, the researchers would conduct the main field testing. This step was also known as the main testing and was conducted in the Nur Hidayah Integrated Islamic Elementary School Surakarta. The method that the researchers implemented was asking the managers of the Integrated Islamic Elementary School to implement the evaluation model that had been designed in order to evaluate the learning process in the school. At the end of the evaluation testing, the respondents were asked to complete the assessment sheet regarding the model that had been implemented in order to assess the format, the substance and the procedures of the evaluation. The results of the reviewer assessment from the Nur Hidayah Integrated Islamic Elementary School Surakarta regarding the P3 Model would be as follows. From the 24 aspects in the assessment toward the evaluation model, 17 aspects achieved the percentage that had been above $76 \%$ (Very Good) while the remaining 7 aspects, namely the page thickness, the evaluation guidelines, the completion time, evaluation implementation, the data analysis, the criteria definition and the evaluation report composition achieved the percentage that had been above $51 \%$ (Good).

The curriculum in the Nur Hidayah Integrated Islamic Elementary School during the evaluation was the Educational Unit Level Curriculum (KTSP, Kurikulum Tingkat Satuan Pendidikan) with the addition of the Integrated Islamic Elementary Schools' peculiarity namely the use of Al-Qur'an verses and hadits in all learning materials including the general ones. There was a cohesive integration within the learning process and all teachers should master the manners of integrating the subjects that they taught and the Al-Qur' an verses and hadits. In general, the results of evaluation toward the curriculum documents of the integrated Islamic elementary school, from the $1^{\text {st }}$ grade to the $6^{\text {th }}$ grade, attained the score 4 with the "Very Good" category. The documents in the form of annual programs, semester programs and lesson plans had been well kept both in the soft files and the hard files. Altogether with the instrument testing, the researchers also evaluated another evaluation in order to identify the school's learning process. Referring to the table of the Integrated Islamic School management criteria in the evaluation guidelines, the results of the Integrated Islamic School learning process evaluation in the Nur Hidayah Integrated Islamic 
Elementary School showed that the school had belonged to the "Very Good" category in the school management with the score of the school had been equal to 3.75 .

Then, the lesson plans in the Nur Hidayah Integrated Islamic Elementary School contained the subject identity, the clear Standard of Competence (SK, Standar Kompetensi), the Basic Competence (KD, Kompetensi Dasar) and the measurable learning indicators. The lesson plans also contained the clear learning objectives with the teaching materials that had been elaborated in accordance with the indicators of achievement. The time allocation was also set appropriately for each learning stage. In the lesson plans the researchers also found the internalization of Islamic values by selecting the learning methods that had been in accordance with the indicators of achievement. In addition, the researchers also found elaboration on the learning activities, the learning assessment methods and tools and the learning media that would be appropriate for achieving the indicators. The learning instruments included the modules, the students' working sheets and the textbooks.

Fourth, the researchers conducted the operational field testing. In this step, the researchers would implement the evaluation model to the respondents in a wider scope, namely in the managers of two integrated Islamic schools located in the ex-Surakarta Residence regions: the Insan Kamil Integrated Islamic Elementary School Karanganyar and the Az Zahra Integrated Islamic Elementary School Sragen. In this stage, the product that the researchers generated was the Integrated Islamic School learning process evaluation instrument that had been expected to attain practical and efficient information regarding the implementation of educational process in the Integrated Islamic Schools. The Az Zahra Integrated Islamic Elementary School was located in the Dr. Soetomo Street, SumbeAsri Village, Sine Sub-County of Sragen, County of Sragen, and the Province of Central Java.
From the 24 aspects of assessment toward the evaluation model, 12 aspects achieved the percentage that had been above $76 \%$ (Very Good) while the remaining 12 aspects achieved the percentage that had been above $51 \%$ (Good). On the other hand, based on the results of an interview with Vice Principal in the Domain of Curriculum, the researchers found that up to date the school usually conducted an internal evaluation in collaboration with the Az Zahra Foundation and the management of the Az Zahra Integrated Islamic Elementary School.

The next testing was conducted in the Insan Kamil Integrated Islamic Elementary School Karanganyar and the testing involved the principal and the teachers. The Insan Kamil Integrated Islamic Elementary School was established in 2005 on an ancientJavanese design boarding house in Cangakan Timur. From the 24 aspects of assessment toward the evaluation model, 20 aspects achieved the percentage that had been above $76 \%$ (Very Good) while the remaining 4 aspects achieved the percentage that had been above $51 \%$ (Good). From the results of the indepth interview, the Principal of Insan Kamil Integrated Islamic Elementary School stated the P3 Model in general might be useful and be implemented for measuring the learning process in the Integrated Islamic Elementary School; however, the model should equipped with the clear parameters, benchmark and measurement. In this case, there should be a document that might strengthen the evaluation results by stating that the learning process in the Integrated Islamic Elementary School had been well implemented.

Based on the evaluation instrument that had been completed by the Insan Kamil Integrated Islamic Elementary School, the researchers attained a description that the learning process had achieved the score 4 with the "Very Good" category. As having been mentioned in the items of learning process evaluation instrument, each year the school routinely analyze the curriculum and the curriculum analysis is conducted by the teachers in the form of Teacher Working 
Group (TWG). Within the curriculum analysis, the teachers should map the Standards of Competence and the Basic Competence, should determine the indicators that included the three learning aspects (cognitive, affective and psychomotor) and should internalize the Islamic values. Within the curriculum analysis for the $1^{\text {st }}$ grade until the $3^{\text {rd }}$ grade, the teachers observe the intersubject association. Then, the teachers define the learning theme. Afterwards, the teachers design the syllabus and the lesson plans.

Based on the results of the main field testing, the researchers revised the product for the preparation of conducting the operational testing. In this part of the step, the draft of the model along with the instruments and their indicators that had been tested in the main field testing would be revised based on the feedbacks provided by the respondents. Similar to the preliminary testing, in the main testing the researchers would revise the instrument of evaluation model that had been tested previously. The feedbacks, the suggestions and the criticisms from the respondents would be made as the revision materials in improving the evaluation model. In overall, the instrument was revised and refined.

Fifth, the researchers revised the product. Along with the further revision for each instrument, the researchers analyzed the data based on the evaluation questionnaire that had been completed by the respondents in order to measure the reliability and the validity of the product; the reliability and validity measurement would be calculated by operating the SPSS 17. The EFA Test by means of SPSS 17 program was conducted in order to test whether a construct had unidimensionality or whether the indicators that had been implemented might be used for confirming a construct or a variable of graduates' competencies or not. If each indicator had been the indicator of construct measurement, then the indicator would have high value of loading factor. The statement implied that the indicator had been valid.

The assumption that underlined whether the factor analysis might be implemented for the construct validity test or not by means of SPSS was that the matrix data should have sufficient correlation. The Bartlett of Sphericity Test had been a statistical test that determined whether there had been any inter-variable coefficient or not. The bigger the sample size was, the more sensitive the Bartlett Test would be in detecting the inter-variable coefficient.

Another test tool that the researchers implemented for measuring the inter-variable inter-correlation level was the Kaiser-MeyesOlkin Measure of Sampling Adequacy (KMO MSA). The KMO value varied from 0 until 1. The value that the researchers desired should be $\geq 0.50$ so that the researchers might perform the actor analysis (Imam, 2009). The followings were the results of factor analysis by means of SPSS 17.

Table 10. Results of Validity and Reliability Test toward the Instrument in the Main Testing

\begin{tabular}{|c|c|c|c|c|c|c|c|}
\hline \multirow{3}{*}{ No } & \multirow{3}{*}{ Evaluation Instrument } & \multirow{3}{*}{$\begin{array}{l}\text { Number of } \\
\text { Indicators }\end{array}$} & \multicolumn{4}{|c|}{ Validity } & \multirow[t]{3}{*}{ Reliability } \\
\hline & & & \multirow[t]{2}{*}{ KMO } & \multirow[t]{2}{*}{$\begin{array}{c}\text { Total \% } \\
\text { Variance }\end{array}$} & \multicolumn{2}{|c|}{$\begin{array}{l}\text { Loading Factor } \\
\text { (principal component } \\
\text { 1) }\end{array}$} & \\
\hline & & & & & Lowest & Highest & \\
\hline 1 & $\begin{array}{l}\text { Learning } \\
\text { Documents }\end{array}$ & 4 & 0.555 & 97.51 & 0.980 & 0.995 & 0.991 \\
\hline 2 & Learning Process & 2 & 0.500 & 99.93 & 0.500 & 0.500 & 0.999 \\
\hline 3 & Curriculum & 3 & 0.589 & 95.25 & 0.960 & 0.995 & 0.975 \\
\hline
\end{tabular}

The Bartlett of Sphericity Test had been a statistical test for determining whether there had been any inter-variable correlation or not. The smaller the Bartlett Test score was $(<0.05)$, the stronger the inter-variable correlation would be. The above table showed 
that all of the Bartlett Test scores had been < 0.05. Then, another test tool that the researchers implemented in order to measure the inter-variable inter-correlation level was the Kaiser-Meyes-Olkin Measure of Sampling Adequacy (KMO MSA). The value that the researchers desired should be $\geq 0.50$ so that the researchers might perform the actor analysis. Based on the above table, all of the KMO values had been $\geq 0.50$. Referring to the scores and the value that had been attained and having comparison with the empirical validity parameters, the researchers would like to conclude that the 20 instruments in the P3 Model had been valid.

In order to complete the validity test of the instrument within the P3 Model, the researchers also performed the reliability test by means of SPSS 17 program. The parameter for determining the instrument reliability in the SPSS 17 was the Alpha Cronbach. An instrument would be considered reliable if the Cronbach Alpha value had been $>0.60$. According to Hair et al. (Hair, Anderson, Tatham, \& Black, 1998) and Imam (2009), if the Alpha Cronbach value had been $<0.60$ then there score indicated that some respondents had provided their answers inconsistently and these answers should be tracked one by one. The inconsistent respondents' answers should be eliminated from the analysis and the Alpha value would increase. The results of reliability test in the main testing showed that all of the instruments in the P3 Model had the Alpha Cronbach value that had been $>0.60$; even in average the score had been above 0.90 . Therefore, the researchers would like to conclude that the instruments of the P3 Model had been reliable.

In order to complete the validity and the reliability test, the researchers also performed a descriptive analysis toward the Integrated Islamic Elementary School reviewers' assessment regarding the P3 Model. The results of descriptive analysis showed that all of the instruments had achieved the percentage that had been above $76 \%$. As a result, the researchers would like to conclude that the instruments of the P3 Model had the "Very Good" category as having been displayed in the following table.

Table 11. Results of Descriptive Analysis toward the Instrument in the Main Testing

\begin{tabular}{clrrl}
\hline No & \multicolumn{1}{c}{ Evaluation Instrument } & Mean & $\%$ & Criteria \\
\hline 1 & Learning Process Document & 3.826 & 95.65 & Very Good \\
2 & Learning Process & 3.536 & 88.40 & Very Good \\
3 & Curriculum & 3.826 & 95.65 & Very Good \\
\hline
\end{tabular}

Based on the results of the previous data analysis, the feedbacks provided by the respondents and the results of in-depth interview, the researchers revised the P3 Model. This part of the step was the final product revision in which the developmental product had been revised based on the experts' feedbacks and suggestions. The revision in this part of the step would be the final testing so that the product that had been generated would be the final product in the form of evaluation model that contained the instruments of Integrated Islamic Elementary School learning process.
As having been conducted in the main testing, in the operational testing the researchers would conduct an EFA Test toward the validity of all instruments by means of SPSS 17. The results of validity test toward all of the evaluation instruments in the P3 Model within the operational testing showed that all of the indicators had been clustered into 1 factor. The situation indicated that the instruments of the P3 Model had been valid. 
Table 12. Results of the Instrument Reliability and Validity Test in the Operational Testing

\begin{tabular}{|c|c|c|c|c|c|c|c|}
\hline \multirow{3}{*}{ No } & \multirow{3}{*}{ Evaluation Instrument } & \multirow{3}{*}{$\begin{array}{l}\text { Number of } \\
\text { Indicators }\end{array}$} & \multicolumn{4}{|c|}{ Validity } & \multirow{3}{*}{$\begin{array}{c}\text { Reliability } \\
\qquad \alpha .\end{array}$} \\
\hline & & & \multirow[t]{2}{*}{ KMO } & \multirow{2}{*}{$\begin{array}{c}\text { Total \% } \\
\text { Variance }\end{array}$} & \multicolumn{2}{|c|}{$\begin{array}{l}\text { Loading Factor } \\
\text { (principal component 1) }\end{array}$} & \\
\hline & & & & & Lowest & Highest & \\
\hline 1 & Learning Process Documents & 4 & 0.581 & 72.29 & 0.735 & 0.917 & 0.870 \\
\hline 2 & Learning Process & 2 & 0.500 & 98.35 & 0.992 & 0.992 & 0.983 \\
\hline 3 & Curriculum & 3 & 0.727 & 99.91 & 0.999 & 1.000 & 1.000 \\
\hline
\end{tabular}

The results of reliability test in the main testing showed that all of the instruments in the P3 Model achieved the Alpha Cronbach that had been $>0.60$. As a result, the researchers would like to conclude that all of the instruments in the P3 Model had been reliable. On the other hand, the results of descriptive analysis showed that all of the instruments achieved the percentage that had been $>76 \%$. Therefore, the researchers would like to conclude that the instruments of the P3 Model had belonged to the "Very Good" criteria.

Table 13. Results of Descriptive Analysis toward the Reviewers' Assessment in the Operational Testing

\begin{tabular}{llccc}
\hline No & $\begin{array}{c}\text { Evaluation } \\
\text { Instrument }\end{array}$ & Mean & $\%$ & Criteria \\
& $\begin{array}{l}\text { Learning Process } \\
\text { Document }\end{array}$ & 3.51 & 85.56 & Very Good \\
2 & Learning Process & 3.55 & 87.98 & Very Good \\
3 & Curriculum & 3.51 & 85.56 & Very Good \\
\hline
\end{tabular}

The final product that had been generated in the study was an Integrated Islamic Elementary School evaluation model (the P3 Model) that would be useful for the integrated Islamic schools for identifying the problems in the learning process, for improving multiple weaknesses, for planning the future programs and for controlling the objective achievement. The P3 Model would be effective if the assessment, review, investigation, observation and analysis had been conducted altogether toward the components of learning process in the integrated Islamic schools and had been based on the authentic data, facts, findings and documents that had been related to the school's components.
In overall, the P3 Model had met the standards of being a tool that might be implemented for evaluation because the model had good reliability and validity both the empirical validity and the content validity. In addition, within the testing in the three schools the P3 Model had been implemented by the managers of the Integrated Islamic Elementary Schools and had been considered "very good" by the reviewers for evaluating the learning process in the Integrated Islamic Elementary School. Furthermore, the P3 Model had also been able to provide whole description and criteria regarding the learning process in the Integrated Islamic Schools.

The final product that had been generated in the study was an integrated Islamic school learning process evaluation model (the P3 Model) that might be implemented as part of the school's control mechanism, learning process monitoring, fundamental data provision and preparation for encountering the external evaluation such as accreditation. If the P3 Model had been a routine for the school, then the school would always be ready with the updated data and information. Even if the data had been asked by the parties who benefitted the school's educational service, such as parents, students, committees, society, integrated Islamic school foundations and formal authorities (educational supervisors, assessors and local education authorities), then the school would be ready for submitting the data or the information to the demanding party. Therefore, the P3 Model should be conducted periodically in order to update the data and the information of the learning process that referred to the standards of evaluation under 
the following criteria: 1) utility; 2) accuracy; 3) feasibility; and 4) propriety.

In order to control the mechanism of Integrated Islamic Schools, the Integrated Islamic School Network (JSIT, Jaringan Sekolah Islam Terpadu) defined the standards of quality for the Integrated Islamic Schools. In the practice, the standards of quality should be interpreted technically in order that the standards might be applied for measuring their achievement including the achievement in the standards of learning process. Therefore, there should be a measuring instrument that might evaluate the integrated Islamic school learning process. Therefore, the researchers would like to present the P3 Model as one of the important components for the assurance of learning process quality standards that had been defined by the Integrated Islamic School Network.

In addition, the results of integrated Islamic school learning process evaluation would be beneficial for identifying the learning process problems, for improving multiple weaknesses, for planning the future programs and for controlling the objective achievement.

The P3 Model would be effective if the assessment, the review, the investigation, the observation and the analysis had been conducted altogether toward the components of integrated Islamic school learning process and had been based on the authentic data, facts, findings and documents that had been related to the components of the school.

The evaluation made use of the descriptive quantitative design that had been supported by the qualitative data as part of clarification with focus on the review of quantitative description toward the integrated Islamic school learning process. The design of the evaluation model was expected to be able to view the facts that occurred in all components of integrated Islamic school learning process so that the facts might be described objectively.
Acting as the evaluators in the evaluation effort was the team from the schools and the foundations under evaluation. Several evaluation components should be completed by the schools themselves in the external evaluation because the model design had been prepared for the school's selfevaluation so that there should be honesty in providing the actual data. However, for the objective data comparison the researchers had prepared the assessment sheet that would be completed by the evaluators from foundation team.

Furthermore, in the P3 Model the researchers had provided a column of explanation that might be supplied with the facts or the findings that the evaluator should report as supporting data. Thereby, the results of P3 Model would not only be in the form of normative scores but also in the form of factual data that explained the meaning behind the scores. The P3 Model had two types of questionnaire that consisted of 117 items. The description of the questionnaire would be provided in the following table.

Table 14. The Evaluation Object and the Item Number in the P3 Model

\begin{tabular}{rlr}
\hline No & \multicolumn{1}{c}{ Evaluation Objects } & \multicolumn{1}{c}{$\begin{array}{c}\text { Item } \\
\text { Number }\end{array}$} \\
\hline 1 & $\begin{array}{l}\text { Learning process } \\
\text { documents }\end{array}$ \\
2 & $\begin{array}{l}\text { Learning process in the } \\
\text { classroom }\end{array}$ \\
3 & Curriculum Document & 57 \\
\hline & \multicolumn{1}{c}{ Total } & 23 \\
\hline
\end{tabular}

In overall, the P3 Model had met the standards of a tool that might be implemented for evaluation because the model had good reliability and validity both the content validity and the empirical validity. In addition, within the testing that had been conducted toward three integrated Islamic elementary schools the model had been implemented by the managers of the Integrated Islamic Elementary Schools and the model had been considered as "Very Good" for evaluating the Integrated Islamic Elementary School by the reviewers. Not only 
that, the model had been to provide overall description and criteria regarding the Integrated Islamic School learning process.

\section{CONCLUSION AND RECOMMENDATION}

Based on the problem formulation and the question research, the researchers would like to draw the conclusions as follows. First, the study has generated the Integrated Islamic Elementary School Evaluation Model (the P3 Model). The P3 Model has been developed by referring to theory of Borg \& Gall that includes: a) information gathering; b) planning; c) preliminary product developing; d) expert judging; e) main product revising; f) main field testing; g) operational product revising; h) operational field testing; and i) final product revising. Second, the P3 Model has "Very Good" effectiveness; it has been proven that more than $76 \%$ of the users in the three Integrated Islamic Elementary Schools have implemented the model easily. In addition, based on the reviewers' assessment the P3 Model has met the standards of a tool that might be implemented for evaluating the Integrated Islamic Elementary School learning process because the P3 Model has the good reliability and validity both the content validity and the empirical (construct) validity. Third, the criteria in the P3 Model might provide factual and overall description regarding the Integrated Islamic Elementary School learning process because the P3 Model has been able to: a) generate the comprehensive school profile; b) improve the learning process periodically; c) assure the implementation of learning process in accordance with the standards of quality defined by the JSIT; and d) prepare the school toward the external evaluation or the accreditation.

It is recommended that learning process should be evaluated using evaluation objects that require reasoning about the documents namely learning process document, learning process in the classroom, and curriculum document. Thus, it is suggested to use the P3 Model. This model is not simply tool to be filled with model information but knowledge constructors who learn about the domain by viewing models and integrating them with prior experience in the learning process.

\section{REFERENCES}

Borg, W. R., \& Gall, M. D. (1984). Educational research: An introduction.

Bouchamma, Y. (2005). Evaluating teaching personnel. which model of supervision do canadian teachers prefer? Journal of Personnel Evaluation in Education, 18(4), 289. https://doi.org/http://dx.doi.org/10.100 7/s11092-007-9025-8

Hair, J. F., Anderson, R. E., Tatham, R. L., \& Black, W. C. (1998). Multivariate data analysis, 5th. NY: Prentice Hall International.

Hidayah, M. (2013). Pengoptimalan Keterampilan Membaca Bahasa Arab Dengan Model Pembelajaran Tutor Sebaya di Kelas VII H MTs Negeri Kendal Tahun 2012/2013. Lisanul'Arab: Journal of Arabic Learning and Teaching, 2(1).

Imam, G. (2009). Analisis Multivariate Dengan Program SPSS, Badan Penerbit Universitas Diponegoro. Semarang.

Mahzar, A. (2004). Revolusi integralisme Islam: Merumuskan paradigma sains dan teknologi Islami. Bandung: Penerbit Mizan.

Muhab, S. (2010). Standar Mutu Sekolah Islam Terpadu. Jakarta: Jaringan Sekolah Islam Terpadu (JSIT) Indonesia.

Syarifuddin, R. (2009). Pengertian Sekolah Islam Terpadu Jaringan Sekolah Islam Terpadu (JSIT) Indonesia. 